all the large fresh-water systems of South America, western North America, and West Africa is due to the fact that the temperature in the deeper layers of the adjacent seas is too low to admit of the propagation." Incidentally, an explanation is afforded of the hitherto puzzling lack of success which attended the transplantation of eels from the eastern to the Pacific States by the U.S.A. Fish Commission in 1874 and other years. The eels themselves flourished in their new surroundings, but the Pacific Ocean afforded no place for successful reproduction.

Oceanic hydrography has thus supplied the indispensable key to the elucidation of a point in the biology of a species which is universally regarded as a fresh-water form. More strictly, however, Anguilla vulgaris may be considered as an oceanic species which has acquired the habit of migrating to fresh water for food and protection.

After all, the most interesting feature of this work is that it deals with an extreme case of the problem of the relationship between physical environment and fish propagation, a most important question in connection with the economic aspect of the fish supply. Dr. Schmidt has contributed pioneer work of great value towards the understanding of these phenomena in regard to other species besides the eel. We may mention, for example, his research upon the plaice and cod in Icelandic waters, where he has shown by marking experiments that a regular spawning migration takes place into the warmer Atlantic water off the south and south-west of the island. Here again the phenomena are clear and comprehensible, because they are, as it were, "writ large"-the difference in temperature between the cold water off the north and east and the warmer Atlantic waters off the south and west of the island being very marked, which renders the migration practically an absolute necessity for the survival of the offspring. Essentially the same in principle are the problems of correlated physics and biology in British seas which still, to a great extent, await elucidation. But here the phenomena are not "writ large" ; on the other hand, they can only be demonstrated by the study of observations made with fine precision and extended over a considerable period of time.

A. E. H.

\section{THE PARIS FLOODS.}

$\mathrm{I}^{\mathrm{T}}$ is now an evident fact that Paris has recently suffered the ravages of an inundation greater and more severe than any which have visited the city within the last two and a half centuries. A gauge at the bridge of La Tournelle shows the surface of the water as having reached a height above the bed of the river of 27 feet $10 \frac{1}{2}$ inches. Normally, it is only about 8 or 9 feet, and it is necessary to go back so far as the year 1658 in order to find any record exceeding, or even approaching, this figure. At that date the height attained was 28 feet Io $\frac{1}{2}$ inches. A few years previously $(165 \mathrm{I})$ there was a flood of 25 feet 8 inches, and in 1649 another of 25 feet 2 inches. The flood of 1802 , great as it was, did not exceed 24 feet 5 inches, and that of 1876 only reached 2 I feet II inches.

The known records are as follows:-

$\begin{array}{lccccccccc}\text { February } & 1649 & \ldots & \ldots & \ldots & \ldots & \ldots & \ldots & 25 & \text { I } \frac{1}{2} \\ \text { January } & 1651 & \ldots & \ldots & \ldots & \ldots & \ldots & \ldots & 25 & 8 \\ \text { February } & 1658 & \ldots & \ldots & \ldots & \ldots & \ldots & \ldots & 28 & 10 \frac{1}{2} \\ \text { February } & 1690 & \ldots & \ldots & \ldots & \ldots & \ldots & \ldots & 24 & 9 \\ \text { March } & 1711 & \ldots & \ldots & \ldots & \ldots & \ldots & \ldots & 25 & 0 \\ \text { December } & 1740 & \ldots & \ldots & \ldots & \ldots & \ldots & \ldots & 25 & 11 \\ \text { February } & 1764 & \ldots & \ldots & \ldots & \ldots & \ldots & \ldots & 24 & 0 \frac{1}{2} \\ \text { January } & 1802 & \ldots & \ldots & \ldots & \ldots & \ldots & \ldots & 24 & 5 \\ \text { March } & 1807 & \ldots & \ldots & \ldots & \ldots & \ldots & \ldots & 22 & 0 \\ \text { January } & 1910 & \ldots & \ldots & \ldots & \ldots & \ldots & \ldots & 27 & 10 \frac{1}{2}\end{array}$

NO. $2 \mathrm{IO} 2$, VOL. 82]
The causes of the flood are not quite so obvious as the effects. At first sight it would appear that there is no very satisfactory explanation to be vouchsafed. In the watershed of the Seine and its tributaries there is an absence of lofty ranges with snow-capped summits, capable of producing copious liquidations such as prevail in mountainous regions. But on the other hand, there are numerous impermeable districts within the Seine Basin where the rainfall finds its way almost entirely into the river bed, and if to the effect of a prolonged precipitation in these areas there be added the far from negligible contribution of melted snow from the impermeable Morvan Plateaux, produced under the influence of a sudden and abnormal rise in temperature, we need not pursue inquiries very much further in order to arrive at an adequate solution of the problem.

The Seine at Paris is formed by the confluence of three important streams: the Yonne, the Upper Seine, and the Marne. Of these the Yonne is the only one presenting torrential characteristics; it rises rapidly, and subsides as quickly. The other two streams move more slowly, and change less abruptly. After a period of heavy rainfall the flood waters of the Yonne arrive first at the point of confluence, reaching it at the end of three or four days, and they produce the greater portion of the rise in level. Four or five days later the waters of the Upper Seine and Marne arrive, having been fed by filtrations through more permeable ground and by surfeited springs, and these simply serve to maintain the effect of the previous increment. If towards the end of this period the previous meteorological phenomena in the upper reaches repeat themselves, the effect produced is that of a single continuous flood of considerable intensity.

Fortunately, floods in the neighbourhood of Paris can be predicted sufficiently in advance to enable remedial, or at any rate palliative, measures to be undertaken. The Seine, as has been pointed out, rises but slowly, and the effects of floods in its affluents are visible several days beforehand, and can be announced accordingly. There is ample warning for the inhabitants to withdraw, if need be, from the threatened quarters. An empirical rule has even been established which enables the height attainable by the flood to be approximately stated. The rise of the Seine at Paris is just about double the mean of the partial rises in its affluents at certain fixed points. The hygrometric service of Paris, therefore, plays a very useful part in issuing these forecasts, and renders valuable service to the community at large.

\section{PROF. F. PURSER}

THE news of the death of Prof. F. Purser, professor of natural philosophy in the University of Dublin, announced in last week's Nature, has been received with deep regret. His life had just reached the regular period of seventy years, and intellectually he was as vigorous as ever.

Prof. Purser was one of the ablest and most brilliant members of a very clever family. His father managed Guinness's Brewery in the time of Sir Benjamin Guinness, and it was to a great extent owing to his skill, foresight, and enterprise that the brewery attained the colossal dimensions it possesses at present. His elder brother was a mathematician of a very high class, and was for several years professor in Queen's College, Belfast.

Two of his cousins were distinguished professors of the University of Dublin. One held the chair of institutes of medicine, or physiology ; the other, Dr. Louis Purser, was professor of Latin, and is still public orator. 
Prof. Purser's university career was very brilliant. He obtained a science scholarship in 1859 , a large gold medal in mathematics, pure and applied, at the moderatorship examination in. 1860 ; Bishop Law's mathematical prize, the MacCullagh prize, and in 1872 fellowship. At that time the fellows of Trinity College, Dublin, were supposed to be members of what had recently been the Established Church, and on their election were obliged to make a declaration which was partly of a religious character. Frederick Purser was a Moravian, and though no question would have been asked as to his special form of belief, he considered that he could not with truth make the required declaration, and consequently the fellowship he had won was declared vacant.

In 1873 Fawcett's Act abolished religious tests in the University of Dublin, and Purser began to read again for fellowship, which he gained for the second time in 1879 . This has always been regarded as a wonderful feat by those who are best acquainted with the nature and difficulty of the fellowship examination in Trinity College. In I902 Purser succeeded Tarleton as professor of natural philosophy, which professorship he held until his death. In 1905 and 1906 he was a vice-president of the Royal Irish Academy. He published in the Proceedings of the Academy some fine papers on the applications of Bessel's function to various difficult questions in physics. Some beautiful investigations of Prof. Purser are to be found in Tarleton's "Introduction to the Mathematical Theory of Attraction." Purser's publications, however, represent most inadequately the extent of his knowledge and his genius.

A more profound or accurate thinker than Prof. Purser it would be difficult to find. $\mathrm{He}$ was not merely a mathematician-he was also a metaphysician of the highest order. His paper, published many years ago in Hermathena, on "Hamilton's System of Natural Realism," was a work of rare ability. In that paper he showed that Hamilton's theory, when stripped of its absurdities and inconsistencies, was almost the same as the theory of Kant. As a metaphysician Prof. Purser was in the main a follower of Kant. Of geometrics of space of more than three dimensions he had a poor opinion, and looked upon them as little more than algebraical exercises.

Possessed of considerable wealth, he expended it with the greatest generosity. $\mathrm{He}$ was a munificent benefactor of Queen's College, Belfast, where his brother was a professor; of Trinity College, Dublin; and of the Roval Irish Academy.

Prof. Purser's chief fault--if it may be described as such-was one which appears to belong to the whole Purser family, that is, the fault of thinking far too little of his own powers and of the value of his own performances.

\section{NOTES}

For the meeting of the British Association for the Advancement of Science, which is to take place this year at Sheffield on August $3 \mathbf{r}$ and following days, under the presidency of Prof. T. G. Bonney, F.R.S., the following presidents have been appointed to the various sections:A (Mathematical and Physical Science), Dr. E. W. Hobson, F.R.S.; B (Chemistry), Mr. J. E. Stead, F.R.S.; C (Geology), Prof. A. P. Coleman; D (Zoology), Prof. G. .C. Bourne; E (Geography), Dr. A. J. Herbertson; F (Economic Science and Statistics), Sir H. Llewellyn Smith, K.C.B.; G (Engineering), Prof. W. E. Dalby; H (Anthropology), Mr. W. Crooke; I (Physiology), Prof. A. B. Macallum, F.R.S.; K (Botany), Prof. J. W. H. Trail, F.R.S.; L (Educational Science), Principal H. A. Miers, F.R.S
IN a speech delivered at Washington last week, Commander Robert E. Peary proposed, on behalf of the Peary Arctic Club, that the National. Geographic Society should unite with the club in the organisation of a United States South Polar Expedition, to start in the autumn of this year. He promised that the Peary Club would lend the Roosevelt for the purposes of the expedition, but stated that he himself would be unable to assume the command in person. The proposal has since been accepted by the directors of the National Geographic Society. All proposals which aim at the extension of knowledge of the Antarctic area are to be welcomed, but now that so many projects for the exploration of the south polar regions are to the fore, it is necessary to consider how Commander Peary's scheme stands in relation to other Antarctic enterprises. The only expedition at present in the field is that under Dr. Jean Charcot on board the Pourquoi Pas, which a year ago penetrated the Antarctic regions to the south of South America. It intended to make its way westwards, and, if possible, undertake a " dash" to the South Pole from the ship's winter quarters. If the expedition makes its way northwards again this season, news of it should be received in the course of the next two months. The British expedition now in course of organisation by Captain Scott will make its headquarters in McMurdo Sound, and, if possible, land a small party on King Edward VII. Land. The expedition proposed by Commander Peary will not interfere with these plans in any way, since it is suggested that its base should be on the opposite side of the Antarctic continent, that is to say, on Coats Land, in the Weddell Sea, south of the Atlantic Ocean. This is the coast which Dr. W. S. Bruce, its discoverer, wishes to make the base of a Scottish Antarctic expedition, and Sir Ernest Shackleton has also stated that if he should go south again he would probably attempt to reach the Pole from the side of the Weddell Sea. An alternative base suggested by Sir Ernest Shackleton is Gaussberg, to the south of the Indian Ocean, off which the German expedition under Dr. Von Drygalski wintered in 1902. Gaussberg is situated on the Antarctic circle; the most southerly known point of Coats Land is just beyond the seventy-fourth parallel, or 960 geographical miles from the Pole, while Cape Royds, in McMurdo Sound, where Captain Scott proposes to winter, is in between $77^{\circ}$ and $78^{\circ}$ south latitude, nearly $75^{\circ}$ geographical miles from the Pole.

Mr. W. BAtrson, F.R.S., and Dr. H. T. Bovey, F.R.S., have been elected members of the Athenæum Club under the provisions of the rule which empowers the annual election by the committee of nine persons "of distinguished eminence in science, literature, the arts, or for public services."

THE Julius Thomsen memorial lecture of the Chemical Society will be delivered on February 17 by Sir Edward Thorpe, C.B., F.R.S.

Four lectures on "The Anatomy and Relationships of the Negro and Negroid Races" will be delivered in the theatre of the Royal College of Surgeons, Lincoln's Inn Fields, by Prof. Arthur Keith (conservator of the museum), on February 14, 16, I8, and $2 \mathrm{I}$. Ladies and gentlemen will be admitted to the lectures on presenting their private visiting cards.

THE annual conversazione of the Selborne Society will be held on Friday, February 18. An address will be given by Sir John Cockburn, K.C.M.G., and a lecture on "Selborne and its Associations with Gilbert White" by Mr. E. J. Bedford. There will be a large display of 